\title{
Response profiles of enteric methane emissions and lactational performance during habituation to dietary coconut oil in dairy cows
}

\author{
M. Hollmann, ${ }^{*}$ W. J. Powers, ${ }^{*} \dagger$ A. C. Fogiel, ${ }^{*}$ J. S. Liesman, ${ }^{*}$ and D. K. Beede ${ }^{* 1}$ \\ *Department of Animal Science, and \\ †Department of Biosystems and Agricultural Engineering, Michigan State University, East Lansing 48824
}

\begin{abstract}
Dietary coconut oil (CNO) can reduce dry matter intake (DMI), enteric methane $\left(\mathrm{eCH}_{4}\right)$ emissions , and milk fat yield of lactating cows. The goals of this research were to examine responses to different $\mathrm{CNO}$ concentrations during the habituation period (34-d) and to evaluate temporal patterns of $\mathrm{DMI}, \mathrm{eCH}_{4}$, and milk fat yield. Treatment diets contained (dry basis): $0.0 \%$ (CNO0), $1.3 \%$ (CNO1.3), $2.7 \%$ (CNO2.7), $3.3 \%$ (CNO3.3), or $4.0 \%$ CNO (CNO4). In experiment 1 , 12 primi- or small secundiparous cows were housed in individual, environmentally controlled rooms and fed CNO0, CNO1.3, CNO2.7, or CNO4. Measurements included DMI, $\mathrm{eCH}_{4}$, and milk yield and composition. Due to a precipitous drop in DMI (26\%), cows fed CNO4 were replaced with cows fed CNO3.3 following d 10. Dietary CNO of $2.7 \%$ or more reduced $\mathrm{eCH}_{4}$ emissions. Reduction was greater with increased $\mathrm{CNO}$ and during the first than the second half of the day. Simultaneously, decline in DMI of cows fed CNO2.7, CNO3.3, or $\mathrm{CNO} 4$ was increasingly precipitous with increased CNO concentration. Total-tract neutral detergent fiber (NDF) digestibility during wk 5 was reduced in cows fed CNO2.7 or CNO3.3, which in part explained concomitantly reduced $\mathrm{eCH}_{4} / \mathrm{DMI}$. In addition, milk fat yield was depressed at an increasing rate in cows fed CNO2.7, CNO3.3, and CNO4. In experiment 2, DMI was measured individually in 12 multiparous cows during habituation to $\mathrm{CNO}$, CNO1.3, CNO2.7, or CNO3.3 for $21 \mathrm{~d}$ before relocation to individual, environmentally controlled rooms. Dietary CNO2.7 or CNO3.3 reduced DMI by d 4 and total-tract NDF digestibility during wk 5. Relocation to individual rooms was associated with a $15 \%$ reduction in DMI, which was not affected by treatment. Results showed that $2.7 \%$ or more dietary $\mathrm{CNO}$ reduced $\mathrm{eCH}_{4}$ and DMI, caused milk fat depression, and decreased NDF digestibility.
\end{abstract}

Received August 7, 2012.

Accepted November 9, 2012.

${ }^{1}$ Corresponding author: beede@msu.edu
Key words: lactational response, enteric methane emission, dietary adaptation

\section{INTRODUCTION}

Feeding coconut oil (CNO) may be one approach to mitigate enteric methane $\left(\mathbf{e C H}_{\mathbf{4}}\right)$ emissions from ruminants (Machmüller, 2006). Coconut oil contains about $75 \%$ medium-chain FA (MCFA; $\mathrm{C}_{8}$ to $\mathrm{C}_{14}$ ) that are otherwise rare in ruminant diets. These FA reduce $\mathrm{eCH}_{4}$ emissions in ruminants (Blaxter and Czerkawski, 1966). However, characterization of $\mathrm{eCH}_{4}$ emissions during habituation to dietary $\mathrm{CNO}$ has not been described in high-producing dairy cows.

Dietary CNO or MCFA treatments resulted in reduction of DMI and consequently lactational performance in dairy cows (Külling et al., 2002; Hollmann et al., 2012; Reveneau et al., 2012). Additionally, dietary CNO or MCFA depressed ruminal NDF digestibility (NDFD; Sutton et al., 1983; Reveneau et al., 2012). Recently, we speculated that at least 2 different mechanisms regulate DMI in cows fed CNO (Hollmann and Beede, 2012). Dry matter intake dropped and stayed depressed 1 to $2 \mathrm{~d}$ following the introduction of $4 \%$ or more (dry basis) dietary CNO. In contrast, DMI declined slowly (e.g., over 1 to 2 wk), when diets contained 2 to $3 \%$ CNO. Dietary FA with 12 or less C are mostly oxidized in ruminants (Blaxter and Czerkawski, 1966); thus, they could depress DMI through accumulation of ATP (Allen et al., 2009). Moreover, dietary $\mathrm{C}_{12}$, the major $\mathrm{FA}$ in $\mathrm{CNO}$, initiated a hormonal response that caused satiety in humans (Feltrin et al., 2004). Oxidation of fuels and hormonal responses to dietary CNO are presumed to be short-term regulators of DMI. In contrast, ruminal fill may build up over time with depressed ruminal NDFD and cause a slow reduction in DMI through ruminal fill limitations (Allen, 1996). The progression of the DMI response to the introduction of CNO at differing dietary concentrations requires further examination.

Ruminal fermentation of NDF generates more $\mathrm{eCH}_{4}$ than digestion of NFC (Blaxter and Clapperton, 1965). Indeed, reduced ruminal NDFD is likely responsible, 
in part, for reduced $\mathrm{eCH}_{4}$ emissions with $\mathrm{CNO}$ diets in ruminants. Yet, it is not feasible to directly assess ruminal NDFD during habituation to dietary treatment. First, NDFD presumably changes daily during the initial stage of CNO feeding, but detecting progression in NDFD is virtually impossible due to diurnal variations (e.g., in intake). Second, evacuation and sampling of ruminal contents would greatly disrupt the continued adaptation to treatment. Additionally, dietary CNO consistently causes milk fat depression (MFD; Hollmann et al., 2012; Reveneau et al., 2012), likely in response to impaired ruminal NDFD (Bauman and Griinari, 2001). Monitoring $\mathrm{eCH}_{4}$ emissions and milk fat production during habituation to dietary treatment may provide insight into ruminal NDFD. Thus, the objective was to evaluate progression of $\mathrm{eCH}_{4}$ emissions, DMI, and milk production during the habituation to introduction of various dietary concentrations of CNO. We hypothesized that (1) high CNO concentration (e.g., greater than $3 \%$, dry basis) will reduce $\mathrm{eCH}_{4}$ emissions and DMI short term, (2) moderate CNO concentrations will depress $\mathrm{eCH}_{4}$ and DMI midterm (e.g., after $1 \mathrm{wk}$ ), and (3) $\mathrm{eCH}_{4}$ emissions per unit of DMI and milk fat yield will decline at an increasing rate with increased dietary $\mathrm{CNO}$ concentrations.

\section{MATERIALS AND METHODS}

The current study examining the adaptation period to introduction of dietary $\mathrm{CNO}$ in lactating dairy cows was part of a larger experiment (Hollmann et al., 2012). The reader is referred to that paper for further description of experimental procedures. The All University Committee on Animal Use and Care at Michigan State University (East Lansing) approved all experimental procedures (approval number 07/07-130-00). Cows were observed and evaluated for potential health issues twice daily.

\section{Treatments and Cows}

All dietary concentrations are presented on a dry basis. Dry matter intakes and milk yields (MY) were recorded daily throughout the experiment. All cows had been fed a basal diet without supplemental fat or monensin-Na for $21 \mathrm{~d}$ before the experiments began at the Michigan State University Dairy Teaching and Research Center (DTRC).

Experiment 1. Dietary treatments had CNO concentrations of $0.0 \%$ (CNO0), $1.3 \%$ (CNO1.3), $2.7 \%$ (CNO2.7), $3.3 \%$ (CNO3.3), or $4.0 \%(\mathbf{C N O} 4)$ and were formulated to meet NRC (2001) recommendations. Dietary ingredients and nutrient compositions are given in Table 1. Briefly, CNO and soybean meal were substituted for portions of soy hulls to maintain similar $\mathrm{CP}$ and amino acids concentrations across treatments.

Eight primiparous and 4 small secundiparous Holstein cows $[116 \pm 30$ DIM (mean \pm SD) at the start of the experiment] were blocked by parity and MY and assigned randomly to CNO0, CNO1.3, CNO2.7, or CNO4. They were relocated and randomly assigned to individual, environmentally controlled rooms at the Animal Air Quality Research Facility on $d-1$. Cows were milked twice daily and fed at least $110 \%$ of their ad libitum DMI per 12-h period before each milking. Treatment diets were prepared daily as a TMR and fed for $34 \mathrm{~d}$. Environmentally controlled rooms and management of cows were described elsewhere (Hollmann et al., 2012).

Cows were offered the preexperimental diet on $\mathrm{d}-1$ (first day in rooms). Dietary treatments started d 1. Treatment CNO4 was discontinued after d 10 because of severe depression in DMI. Cows fed CNO4 (2 primiparous and 1 secundiparous cow) were removed from the experiment. They were replaced on d 12 with 3 different cows (2 primiparous and 1 secundiparous cow) that had been fed CNO0, CNO1.3, or CNO2.7 for 11 $\mathrm{d}$ at the DTRC. Replacement cows received CNO3.3. The average DIM for all 12 cows on d 12 was 126 (SD: $\pm 30)$. Primiparous cows weighed $569( \pm 36.7) \mathrm{kg}$ and secundiparous cows weighed $633( \pm 50.1) \mathrm{kg}$ after the morning milking on $\mathrm{d} 34$.

Experiment 2. Twelve multiparous cows $[129 \pm 15$ DIM (mean $\pm \mathrm{SD}$ ) at the start of the experiment] at the DTRC were blocked by MY and randomly assigned to CNO0, CNO1.3, CNO2.7, or CNO3.3. Cows were fed once daily ad libitum in a tiestall barn, milked twice per day in a parlor, and given access to an exercise lot for $1 \mathrm{~h}$ daily. They were relocated and kept in individual, environmentally controlled rooms at the Animal Air Quality Research Facilities from d 22 to 36 and managed as described for experiment 1.

\section{Data and Sample Collections and Analyses}

Experiment 1. Methane concentrations in incoming and out-flowing air streams were detected for each room during eight 5.5-min periods per day (variable: time of day) with a photoacoustic analyzer (Innova model 1412; LumaSense Technologies A/S, Ballerup, Denmark). A pressure transducer (Setra model 239; Setra Systems Inc., Boxborough, MA) measured air flow in and out of each room, and temperature and relative humidity of outlet air were recorded (CS500; Campbell Scientific Inc., Logan, UT; Li et al., 2011). Enteric $\mathrm{CH}_{4}$ emissions were the difference between amount of $\mathrm{CH}_{4}$ entering and exiting each individual room. Enteric $\mathrm{CH}_{4}$ data were not available for $\mathrm{d}-1,1,19$, and 32 , 
Table 1. Ingredient and analyzed nutrient composition of experimental diets

\begin{tabular}{|c|c|c|c|c|c|}
\hline Item & \multicolumn{5}{|c|}{ Treatment $^{1}$} \\
\hline \multicolumn{6}{|l|}{ Ingredient, $\%$ of DM } \\
\hline Alfalfa haylage ${ }^{3}$ & 7.4 & 7.4 & 7.4 & 7.4 & 7.4 \\
\hline Grass silage $^{4}$ & 5.5 & 5.5 & 5.5 & 5.5 & 5.5 \\
\hline Ground corn & 24.1 & 24.1 & 24.2 & 24.2 & 24.2 \\
\hline Heat-processed soybean meal $^{5}$ & 9.9 & 9.9 & 9.9 & 9.9 & 9.9 \\
\hline Wheat middlings & 5.5 & 5.5 & 5.5 & 5.5 & 5.5 \\
\hline Corn gluten meal & 0.9 & 0.9 & 0.9 & 0.9 & 0.9 \\
\hline Urea & 0.6 & 0.6 & 0.6 & 0.6 & 0.6 \\
\hline Mineral-vitamin $\operatorname{mix}^{6}$ & 2.5 & 2.5 & 2.5 & 2.5 & 2.5 \\
\hline \multicolumn{6}{|l|}{ Nutrient composition, $\%$ of DM } \\
\hline Starch & 28.2 & 29.4 & 29.8 & 30.4 & 30.0 \\
\hline $\mathrm{EE}$ & 5.0 & 5.6 & 6.6 & 7.4 & 7.9 \\
\hline $\mathrm{CP}$ & 16.4 & 16.4 & 17.2 & 16.3 & 16.3 \\
\hline Rumen-undegradable $\mathrm{CP}^{7}$ & 6.0 & 6.0 & 5.9 & 5.9 & 5.9 \\
\hline $\mathrm{GE}, \mathrm{Mcal} / \mathrm{kg}$ & 4.26 & 4.43 & 4.50 & 4.48 & 4.52 \\
\hline
\end{tabular}

${ }^{1}$ Treatments were 0 (CNO0), 1.3 (CNO1.3), 2.7 (CNO2.7), 3.3 (CNO3.3), and 4.0\% (CNO4) coconut oil (CNO) in total dietary DM.

${ }^{2}$ Corn silage contained $28.0 \%$ DM (as fed), and $95.4 \%$ OM, $46.1 \%$ NDF, $8.8 \%$ indigestible NDF, $22.2 \%$ starch, $5.4 \%$ ether extract (EE), $8.5 \%$ $\mathrm{CP}$, and $4.41 \mathrm{Mcal} / \mathrm{kg}$ of gross energy (GE); dry basis.

${ }^{3}$ Alfalfa haylage contained $37.7 \%$ DM (as fed), and 90.9\% OM, $44.4 \%$ NDF, $22.1 \%$ indigestible NDF, $0.8 \%$ starch, $6.0 \%$ EE, $19.0 \%$ CP, and 4.74 $\mathrm{Mcal} / \mathrm{kg}$ of GE (dry basis).

${ }^{4}$ Grass silage contained 29.6\% DM (as fed), and 91.4\% OM, 63.9\% NDF, $18.2 \%$ indigestible NDF, $0.3 \%$ starch, $5.7 \%$ EE, $11.5 \%$ CP, and 4.57 $\mathrm{Mcal} / \mathrm{kg}$ of GE (dry basis).

${ }^{5}$ SoyPLUS (West Central Cooperative, Ralston, IA).

${ }^{6}$ Mineral-vitamin mix contained $43.1 \%$ limestone, $31.3 \%$ sodium bicarbonate, $9.7 \%$ magnesium sulfate, $8.1 \%$ sodium chloride, $3.0 \%$ trace minerals (contained $11.6 \% \mathrm{Ca}, 9.1 \% \mathrm{P}, 5.0 \% \mathrm{Fe}, 4.0 \% \mathrm{Mn}, 4.0 \% \mathrm{Zn}, 1.0 \% \mathrm{Cu}, 600 \mathrm{mg}$ of I $/ \mathrm{kg}, 300 \mathrm{mg}$ of Se $/ \mathrm{kg}$, and $200 \mathrm{mg}$ of Co/kg), $2.5 \% \mathrm{biotin}$ $(1.4 \mathrm{~g} / \mathrm{kg}), 0.6 \%$ selenium yeast, $57 \mathrm{kIU}$ of vitamin A/ $\mathrm{kg}, 17 \mathrm{kIU}$ of vitamin D/ $\mathrm{kg}$, and $0.8 \mathrm{kIU}$ of vitamin E/ $\mathrm{kg}$ (dry basis).

${ }^{7}$ Estimated from published values (NRC, 2001).

and for some additional partial days due to equipment malfunction. Overall, reliable $\mathrm{eCH}_{4}$ data were available for $78.8 \%$ of all possible 3 -h gas sampling periods $(\mathrm{n}=$ $3,319)$.

Milk was sampled during each milking on $\mathrm{d}-1$ and then at each Monday and Wednesday p.m. milkings and Tuesday and Thursday a.m. milkings. Milk samples were analyzed for concentrations of fat, true protein, and lactose by mid-infrared spectroscopy (AOAC, 1990) by Michigan Dairy Herd Improvement Association (East Lansing, MI) and solids-corrected MY (SCMY) was calculated (Tyrrell and Reid, 1965), with a correction factor of 20/19 for conversion of milk true protein to milk CP based on results from Verdi et al. (1987).

Dry matter content of forages was determined twice per week, and diets were adjusted accordingly to maintain dietary DM formulation. Additionally, samples of forages and concentrate premixes were collected and frozen $\left(-20^{\circ} \mathrm{C}\right)$ twice weekly. Fecal matter was sampled per rectum following each milking on d 27 through 34 and frozen. Dried $\left(60^{\circ} \mathrm{C}\right)$ feed and fecal samples were ground through a Wiley mill (1-mm screen; Arthur H. Thomas Co., Philadelphia, PA) and pooled within individual ingredient or cow, respectively, based on $105^{\circ} \mathrm{C}$ DM. Concentrations of NDF were analyzed (Van Soest et al.,1991, method A). Indigestible NDF was determined as ash-free NDF residue after a 240-h in vitro fermentation (Goering and Van Soest, 1970) with a repeated inoculation at $120 \mathrm{~h}$. This served as an endogenous marker for total-tract NDFD. Ruminal fluids for in vitro fermentation were from 2 nonpregnant, nonlactating cows fed solely grass hay. Further feed composition analyses were as described in Hollmann et al. (2012).

Experiment 2. Dry matter intake was calculated daily based on weights of feed offered and refused while cows were housed in the tiestall barn (d 1 to 21 ), and as described for experiment 1 while cows were housed 
at the Animal Air Quality Research Facilities. Fecal samples were taken and total-tract NDF digestibility was assessed as in experiment 1.

\section{Statistical Analyses}

Experiment 1. Statistical analyses were conducted using mixed effects models (PROC MIXED, SAS 9.1.3; SAS Institute Inc., Cary, NC). Data were standardized with regard to days after introduction of treatment because CNO3.3 was introduced on $\mathrm{d} 12$ of the experiment. Thus, d 1 of CNO3.3 was not the same Julian day as $\mathrm{d} 1$ of the other 4 treatments. Enteric $\mathrm{CH}_{4}$ data were analyzed as a split-split plot design with dietary treatment as the main plot, day as the split plot, and time of day as the split-split plot. This approach accounted for the repeated measure of time of day within the repeated measure of day under the assumptions of constant correlation and variances across time of day within day and across days within room nested in treatment. The model contained the fixed effects of dietary treatment $(\mathrm{n}=5)$, day $(\mathrm{n}=31)$, time of day $(\mathrm{n}=8)$, and their interactions. Individual room was the experimental unit for $\mathrm{CH}_{4}$ emissions and individual cow for lactational performance. Random effects were room nested within treatment as error term for the main plot, the interaction of room (containing an individual cow) within treatment and day as error term for the split plot, and the interaction of room within treatment by day by time of day as error term for the split-split plot. Degrees of freedom were approximated by the Satterthwaite equation in SAS. The SINGULAR option of SAS was set at 0.4 to estimate least squares means from $\mathrm{eCH}_{4}$ data, because of missing observations of $\mathrm{eCH}_{4}$. The chosen value was nearest to 1 and least squares means were provided for most days and all times of day for all treatments. The $\mathrm{eCH}_{4}$ data were $\log$ transformed so that residuals were normally distributed. Lactational performance data were analyzed as a split plot similar to $\mathrm{eCH}_{4}$ data without the main effect of time of day and its error term. The variable day was the repeated measure with variance components as the variance-covariance structure based on the lowest Bayesian information criterion in SAS. Dietary treatments CNO0, CNO1.3, and CNO2.7 were evaluated based on the entire length of the experiment, whereas CNO3.3 and CNO4 were evaluated based on data through d 22 and 10, respectively. Thus, 3 data sets were used: $\mathrm{d} 1$ to 10 to evaluate $\mathrm{CNO} 4$, d 1 to 22 for CNO3.3, and d 1 to 34 for CNO0, CNO1.3, and CNO2.7. Analyses of SCMY and milk components used data from $\mathrm{d}-1$ as covariate, if covariate interaction with treatment was significant at $P<0.10$, as in the case for milk fat yield.
Experiment 2. Dry matter intake data were analyzed as a split plot as described for experiment 1 . The data set was evaluated in its entirety and also divided into 2 periods, with period 1 encompassing d 1 through 21 (cows kept in a conventional tiestall barn at DTRC) and period 2 encompassing d 23 through 36 (following the relocation in individual, environmentally controlled rooms following d 21). Dry matter intakes before relocation (d 15 through 21) and postrelocation (d 23 through 29) were averaged by cow, and significant differences between the 2 periods were determined with Student's $t$-test to examine effect of relocation on DMI.

Significance was declared at $P<0.05$ and tendencies at $P<0.10$ for main fixed effects and $P<0.15$ for interactions in both experiments as recommended by Littell et al. (2002), to reduce type II error and because significance is more difficult to determine for interactions than for main effects. The SLICE option in SAS was used for separation of effects of individual treatments across all days or of all treatments for individual days. Essentially, a change over time on treatment indicated a change over several days induced by treatment.

\section{RESULTS AND DISCUSSION}

Results from experiment 1 are discussed for all dietary treatments from d 1 to 10 , all dietary treatments except CNO4 for d 1 to 22, and for CNO0, CNO1.3, and CNO2.7 for d 1 to 34. Results for only DMI from experiment 2 are presented and discussed, because MY, milk composition, and $\mathrm{eCH}_{4}$ emissions were not recorded on d 1 through 21 while cows were housed at the DTRC.

\section{Enteric $\mathrm{CH}_{4}$ Emissions}

An interaction of dietary $\mathrm{CNO}$ concentration and days following the introduction of treatments tended to affect $\mathrm{eCH}_{4}$ emissions from d 2 to $10(P<0.07$; Table $2)$. The interaction was characterized by a continuous decrease in $\mathrm{eCH}_{4}$ emissions in cows fed CNO4 $(P<0.01$; Figure 1) and a temporary decrease in $\mathrm{eCH}_{4}$ emissions from cows fed CNO2.7 $(P<0.001)$. Furthermore, by d $2, \mathrm{eCH}_{4}$ emissions already were $46 \%$ lower (an estimated $247 \mathrm{~g} / \mathrm{d}$ ) for CNO4-fed cows than for cows fed CNO0, CNO1.3, or CNO2.7. Overall, cows fed CNO4 emitted less $\mathrm{eCH}_{4}(170 \mathrm{~g} / \mathrm{d} ; P<0.01$; Table 2$)$ than cows fed CNO0 (414 g/d), CNO1.3 (392 g/d), or CNO2.7 (345 $\mathrm{g} / \mathrm{d})$ from d 2 through 10. Cows fed CNO3.3 emitted an estimated $247 \mathrm{~g} / \mathrm{d}$ from d 2 through 10 without significant variation across that period $(P>0.15)$. During that time, $\mathrm{eCH}_{4}$ emissions of cows fed CNO3.3 were intermediate to those fed CNO4 and those fed less than $3.3 \%$ CNO. However, $\mathrm{eCH}_{4}$ emissions of CNO3.3-fed 
cows were potentially influenced because 2 cows had been fed CNO before starting CNO3.3 and the start of CNO3.3 treatment was delayed. No evidence existed that $\mathrm{eCH}_{4}$ emissions were lower in cows fed CNO3.3 immediately following introduction of treatment than in cows fed less than $3.3 \% \mathrm{CO}$, when $\mathrm{eCH}_{4}$ emissions were analyzed by Julian day (results not shown). In that scenario, $\mathrm{eCH}_{4}$ emissions from cows fed CNO3.3 tended to differ $(P<0.10)$ from those fed $\mathrm{CNO} 0$ or CNO1.3 after d 5 of treatments. Moreover, $\mathrm{eCH}_{4}$ emissions in cows fed CNO2.7 were and stayed lower after $16 \mathrm{~d}$ of dietary treatment (Figure 1). Apparently, mitigation of $\mathrm{eCH}_{4}$ emissions reached a state of chronic habituation to dietary CNO following approximately $21 \mathrm{~d}$ of feeding CNO2.7 or $7 \mathrm{~d}$ of feeding CNO3.3.

We evaluated the diurnal variation in $\mathrm{eCH}_{4}$ emissions by dietary treatment (Figures $2 \mathrm{~A}$ through $2 \mathrm{C}$ ). Data were analyzed for each 3 -h period for d 2 through $10, d$ 11 through 22 , and d 22 through 34 , because $\mathrm{eCH}_{4}$ emissions were reduced for $\mathrm{CNO} 4, \mathrm{CNO} 3.3$, and $\mathrm{CNO} 2.7$ in those time frames, respectively. Interactions of dietary $\mathrm{CNO}$ concentration and time of day explained some of the variation in $\mathrm{eCH}_{4}$ emissions in all 3 time frames $(P<0.01)$. Interestingly, these interactions were, in part, based on a greater reduction in $\mathrm{eCH}_{4}$ emissions from 0000 to $1200 \mathrm{~h}$ than from 1200 to $2400 \mathrm{~h}$. Cows fed $\mathrm{CNO} 4$ emitted an estimated $62 \%$ less $\mathrm{eCH}_{4}$ than CNO0-fed cows between 0000 and $1200 \mathrm{~h}$, compared with an estimated 55\% reduction between 1200 and $2400 \mathrm{~h}$ from d 2 through 10 (Figure 2A). Likewise, mitigation of $\mathrm{eCH}_{4}$ emissions was an estimated 45 versus $33 \%$ for cows fed CNO3.3 from d 11 through 22 (Figure 2B) and 49 versus $36 \%$ for cows fed CNO2.7 from d 23 through 34 (Figure 2C). It is not clear whether the greater reductions during the first half of the day were the direct result of dietary CNO concentration on ruminal fermentation or a change in diurnal DMI pattern. Overall, $\mathrm{eCH}_{4}$ emissions differed for all treatments across the day $\left(P_{\text {time of day }}<0.001\right)$ and peaked following the afternoon feeding (1800 through $2100 \mathrm{~h}$; Figures $2 \mathrm{~A}$ to $2 \mathrm{C}$ ). Cows consumed most of the dietary DM $(\sim 60 \%)$ during the night (1800 through $0600 \mathrm{~h}$ ). Emissions were lowest in the early morning hours, but increased after the morning feeding. This emissions pattern was consistent with that reported for a herd of lactating dairy cows with a similar, twice-per-day offering of feed (Kinsman et al., 1995).

\section{DMI}

Experiment 1. An interaction of dietary CNO concentration and days following the introduction of dietary treatments affected DMI during the initial 10 $\mathrm{d}(P<0.04 ;$ Table 2$)$. Specifically, DMI of cows fed
CNO4 decreased $26 \%$ by d 2 and $34 \%$ by d 10 compared with preexperimental DMI $(P<0.05$; Figure $3 \mathrm{~A})$. Because of the precipitous drop in DMI $(6.9 \mathrm{~kg} / \mathrm{d}$ by d 10), CNO4 treatment was discontinued after $\mathrm{d}$ 10. Similar to the present results, DMI of cows fed 4 or $5 \%$ CNO decreased precipitously within $1 \mathrm{~d}$ (Hollmann and Beede, 2012). Dry matter intake on $d-1$ was lower in the current study than in our previous experiment (Hollmann and Beede, 2012), but the decrease in DMI with $\mathrm{CNO} 4$ treatment was proportionally similar.

In contrast to CNO4-fed cows, the DMI decrease of cows fed CNO3.3 or CNO2.7 was less dramatic and occurred between $\mathrm{d} 1$ and $22(P<0.001)$ or $\mathrm{d} 1$ and 34 $(P<0.001)$, respectively (Figure $3 \mathrm{~A})$. This is evident from interactions of dietary treatment and day after the introduction of treatments $(P<0.001$; Table 2). Dry matter intake in cows fed CNO1.3 was relatively consistent throughout the experiment $(P>0.2$; Figure 3A).

Patterns of $\mathrm{eCH}_{4}$ emissions correlated positively with those of DMI. Therefore, we computed the ratio of $\mathrm{eCH}_{4}$ emissions per unit of DMI (Figure 4) and examined whether DMI explained the variation in $\mathrm{eCH}_{4}$ emissions. Dietary treatments interacted with day after the introduction of treatments for $\mathrm{d} 2$ to $10(P<0.02)$, d 2 to $22(P<0.01)$, and tended to interact for $\mathrm{d} 2$ to $34(P<0.15)$. Enteric $\mathrm{CH}_{4}$ emissions per unit of DMI decreased over time in cows fed CNO4 or CNO2.7 ( $P$ $<0.001)$ and tended to differ over time for those fed CNO3.3 $(P<0.07$; Figure 4$)$. Reduction of $\mathrm{eCH}_{4}$ emissions per unit of DMI occurred by d 3 for CNO4-fed cows and by d 26 for CNO2.7-fed cows. Furthermore, mitigation was less in CNO3.3-fed cows compared with CNO0-fed cows by d 7 when analyzed by Julian day $(P$ $<0.05$; results not shown). Overall, temporal patterns of $\mathrm{eCH}_{4}$ mitigation per unit of DMI (based on a treatment by time on treatment interaction) suggest involvement of mechanism(s) other than a simple substitution of ruminally digestible carbohydrates with CNO.

Experiment 2. An interaction of dietary $\mathrm{CNO}$ concentration with day of the experiment characterized DMI in multiparous cows that were introduced to treatment diets in the tiestall barn for $21 \mathrm{~d}$ (period 1; $P<0.01$; Figure 3B). Dry matter intake differed $(P<$ $0.05)$ by dietary CNO concentration by $\mathrm{d} 4$. This indicated the gradual decrease in DMI of cows fed CNO2.7 and CNO3.3. In contrast, decrease in DMI of cows fed CNO4 in experiment 1 was apparent within $2 \mathrm{~d}$, suggesting that the decrease in DMI of CNO4-fed cows was precipitous and not as gradual as with lower dietary CNO concentrations. Thus, the delayed and gradual DMI response to CNO2.7 and CNO3.3 are in stark difference to the precipitous decrease in DMI in CNO4-fed cows in experiment 1. 
Table 2. Enteric methane $\left(\mathrm{CH}_{4}\right)$ emissions and lactational performance during the habituation to diets with different concentrations of coconut oil $(\mathrm{CNO})^{1}$ in primiparous and small secundiparous lactating dairy cows (experiment 1 )

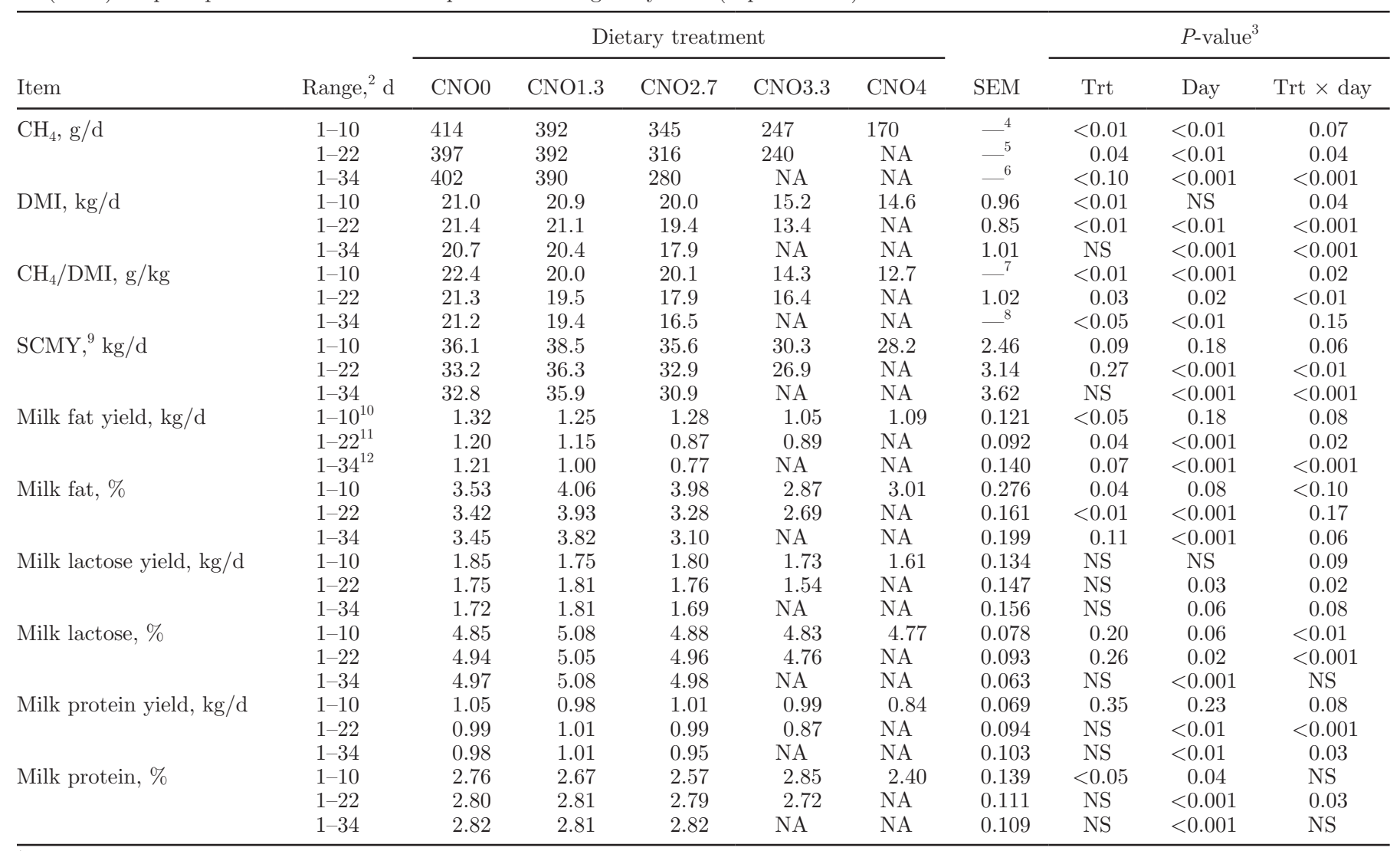

${ }^{1}$ Treatment diets were CNO0 (0.0\% CNO; dry basis), CNO1.3 (1.3\% CNO), CNO2.7 (2.7\% CNO), CNO3.3 (3.3\% CNO), and CNO4 (4.0\% $\mathrm{CNO}) . \mathrm{NA}=$ not available.

${ }^{2}$ Days after introduction of dietary treatments included in analysis. Cows fed CNO4 were on treatment for $10 \mathrm{~d}$; cows were fed CNO3.3 for 22 $\mathrm{d}$; and cows were fed CNO0, CNO1.3, or CNO2.7 for $34 \mathrm{~d}$.

${ }^{3}$ Trt $=$ effect of dietary treatment; day $=$ individual days within period. See Figures $1 \mathrm{~A}$ and 2 to 7 for details of interactions. NS $=$ nonsignificant at $P>0.40 ; \mathrm{n}=3$ for every treatment.

${ }^{4}$ Data were transformed with the natural log: $\left[\mathrm{CH}_{4}\right]_{\text {transformed }}=\ln \left[\mathrm{CH}_{4}\right]$. Pooled log-transformed SEM $=0.116 ; 95 \% \mathrm{CI}(\mathrm{g} / \mathrm{d}): \mathrm{CNO0}: 310$ to 552 ; CNO1.3: 294 to 523; CNO2.7: 259 to 460; CNO3.3: 186 to 328; CNO4: 127 to 226.

${ }^{5}$ Data were transformed with the natural log: $\left[\mathrm{CH}_{4}\right]_{\text {transformed }}=\ln \left[\mathrm{CH}_{4}\right]$. Log-transformed SEM $=0.116 ; 95 \%$ CI $(\mathrm{g} / \mathrm{d}):$ CNO0: 304 to 518 ; CNO1.3: 300 to 511; CNO2.7: 244 to 415; CNO3.3: 184 to 313

${ }^{6}$ Data were transformed with the natural log: $\left[\mathrm{CH}_{4}\right]_{\text {transformed }}=\ln \left[\mathrm{CH}_{4}\right]$. Log-transformed SEM $=0.0051 ; 95 \%$ CI (g/d): CNO0: 310 to 522; CNO1.3: 301 to 506; CNO2.7: 216 to 363.

${ }^{7}$ Data were transformed with the reciprocal: $\left[\mathrm{CH}_{4}\right]_{\text {transformed }}=1 /\left[\mathrm{CH}_{4}\right]$. Transformed SEM $=0.107 ; 95 \% \mathrm{CI}$ (g/kg): CNO0: 17.9 to $29.9 ; \mathrm{CNO} 1.3$ : 16.3 to 25.8 ; CNO2.7: 16.4 to 26.0; CNO3.3: 12.3 to 17.0; CNO4: 11.1 to 14.8

${ }^{8}$ Data were transformed with the reciprocal and root: $\left[\mathrm{CH}_{4}\right]_{\text {transformed }}=\left(1 /\left[\mathrm{CH}_{4}\right]\right)^{0.15}$. Transformed SEM $=0.0052 ; 95 \% \mathrm{CI}(\mathrm{g} / \mathrm{kg}): \mathrm{CNO} 0: 18.5$ to 24.2; CNO1.3: 17.0 to 22.2; CNO2.7: 14.6 to 18.9.

${ }^{9}$ Solids-corrected milk yield (Tyrrell and Reid, 1965) with a milk true protein correction factor of 0.95 (Verdi et al., 1987).

${ }^{10}$ Tendency for interaction of covariate $(\mathrm{d}-1)$ fat yield with treatment $(P<0.08)$.

${ }^{11}$ Interaction of covariate $(\mathrm{d}-1)$ fat yield with treatment $(P<0.05)$.

${ }^{12}$ Tendency for interaction of covariate $(\mathrm{d}-1)$ fat yield with treatment $(P<0.08)$.

A tendency for an interaction of dietary $\mathrm{CNO}$ concentration and days after introduction of treatments $(P$ $<0.12$; Figure 3B) existed for the period following the relocation of the cows into the individual environmental rooms. This interaction had little apparent biological meaning. Across both periods in experiment 2, cows fed CNO1.3, CNO2.7, and CNO3.3 reduced DMI by 11, 23, and $23 \%$, respectively, compared with those fed CNO0 $(P<0.01)$.

The pattern of DMI response to different $\mathrm{CNO}$ concentrations in experiment 2 was more similar to our previous results (Hollmann and Beede, 2012) than the pattern in experiment 1 with regard to the time lag until onset of DMI reduction. Dry matter intake results 


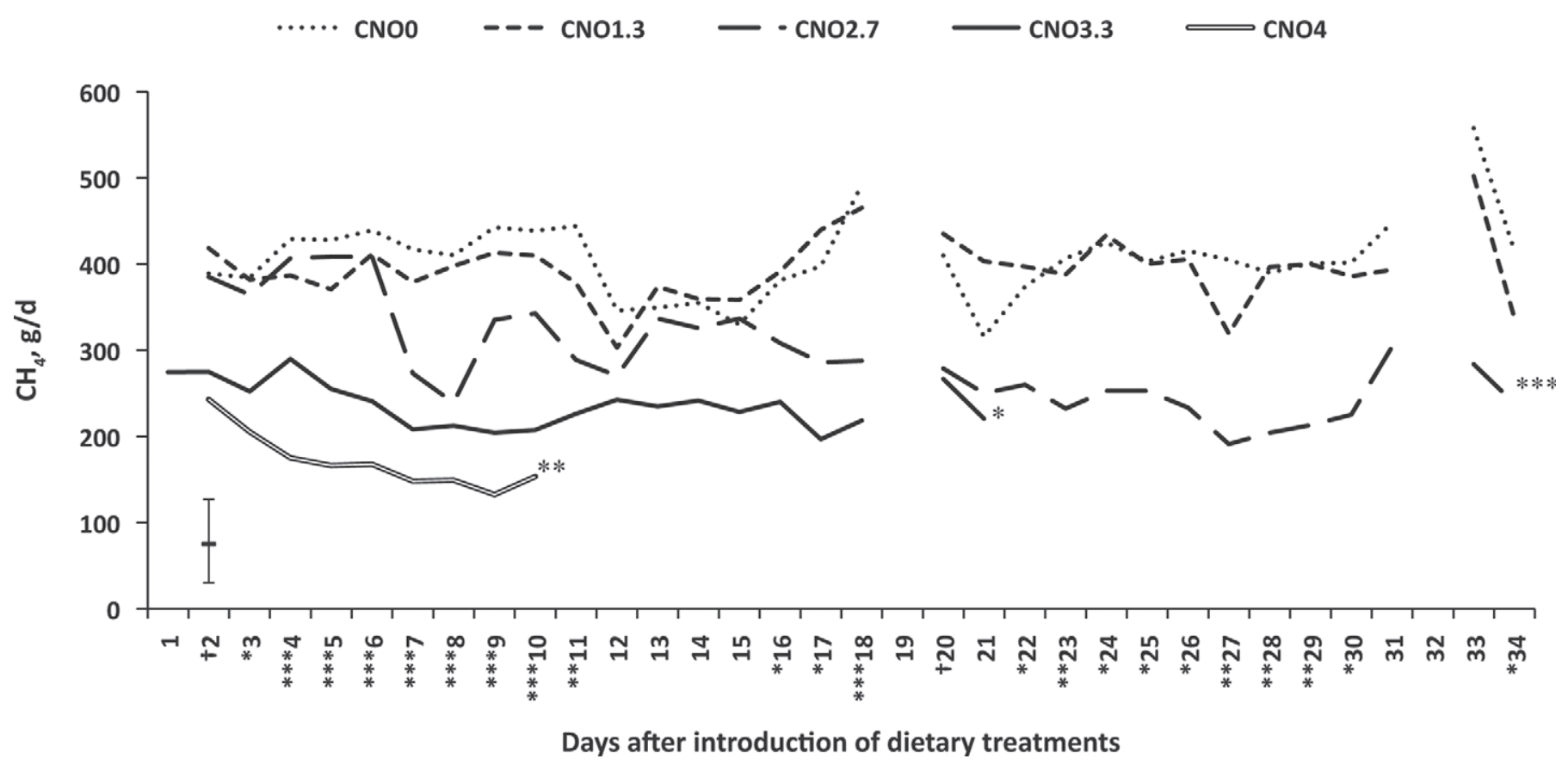

Figure 1. Enteric methane $\left(\mathrm{CH}_{4}\right)$ emissions during the habituation to different concentrations of dietary coconut oil (CNO) in primiparous and small secundiparous lactating dairy cows (experiment 1). Treatment diets were CNO0 (0.0\% CNO; dry basis), CNO1.3 (1.3\% CO), CNO2.7 $(2.7 \% \mathrm{CO})$, CNO3.3 (3.3\% CO), and CNO4 (4.0\% CO). Cows fed CNO4 were removed from the experiment after $10 \mathrm{~d}$. Cows fed CNO3.3 began the experiment following the removal of CNO4-fed cows. Data were not available for d 1, 19, and 32 of the experiment. Pooled SEM ( \pm 48.3$)$ is shown. Symbols indicate significance of treatment within day (on $\mathrm{x}$-axis) and within individual treatments pooled across days (in plot): $\nmid P<$ $0.10 ;{ }^{*} P<0.05 ;{ }^{* *} P<0.01 ; * * * P<0.001$.

from experiment 2 may be more useful than those from experiment 1 for 2 reasons. First, there was no confounding factor of time in introduction of treatments in experiment 2 compared with experiment 1 , where CNO3.3 was introduced with a 12-d delay; and second, cows were habituated to diets in a known environment compared with recently relocated cows in experiment 1. Indeed, DMI declined by $15 \%$ across all treatments when experiment 2 cows were moved from the tiestall barn into the individual environmental rooms $\left(P_{2 \text {-paired }}\right.$ ${ }_{t \text {-test }}<0.001 ;$ Figure 3B). This DMI depression was not affected by dietary treatment $(P>0.4)$. Thus, the potential of altered feeding behavior and reduced performance must be considered when evaluating the results from cows kept for extended periods in individual, environmentally controlled rooms.

The general reduction in DMI of cows fed CNO diets was consistent with other reports (Jordan et al., 2006; Reveneau et al., 2012); however, the immediate response following the introduction of dietary $\mathrm{CNO}$ is rarely reported. Increasing dietary concentration of CNO reduced DMI linearly $(P<0.01)$, but not quadratically $(P>0.5)$ in experiment 2 . This response was consistent with the results from the larger experiment where we evaluated effects during wk 5 of offering dietary CNO (Hollmann et al., 2012). The different tem- poral patterns in response to initial and early feeding of dietary $\mathrm{CNO}$ suggest multiple underlying mechanisms for the DMI response. These cannot be identified by only measuring responses to a treatment after longer term feeding of CNO.

\section{NDF Digestion}

Total-tract NDFD was assessed at wk 5 only. Thus, NDFD results are only available after longer term feeding and not as cows adapted to initial introduction of CNO.

Experiment 1. Dietary CNO concentration tended to affect total-tract NDFD during wk $5(P<0.06)$. Digestibility coefficients were 0.498 (CNO0), 0.502 (CNO1.3), 0.348 (CNO2.7), and 0.346 (CNO3.3; SEM $=0.0441)$. Amounts of NDF digested in the total tract were $3.7,3.7,2.0$, and $1.6 \mathrm{~kg} / \mathrm{d}(\mathrm{SEM}=0.37)$, respectively, and differed by treatment $(P<0.01)$.

Experiment 2. Increased dietary CNO concentrations depressed total-tract NDFD during wk $5(P<$ 0.001). Digestibility coefficients were 0.539 (CNO0), 0.534 (CNO1.3), 0.401 (CNO2.7), and 0.363 (CNO3.3; $\mathrm{SEM}=0.0224)$. This translated to amounts of NDF digested of $4.6,3.9,2.4$, and $2.2 \mathrm{~kg} / \mathrm{d}(\mathrm{SEM}=0.27)$, respectively. 


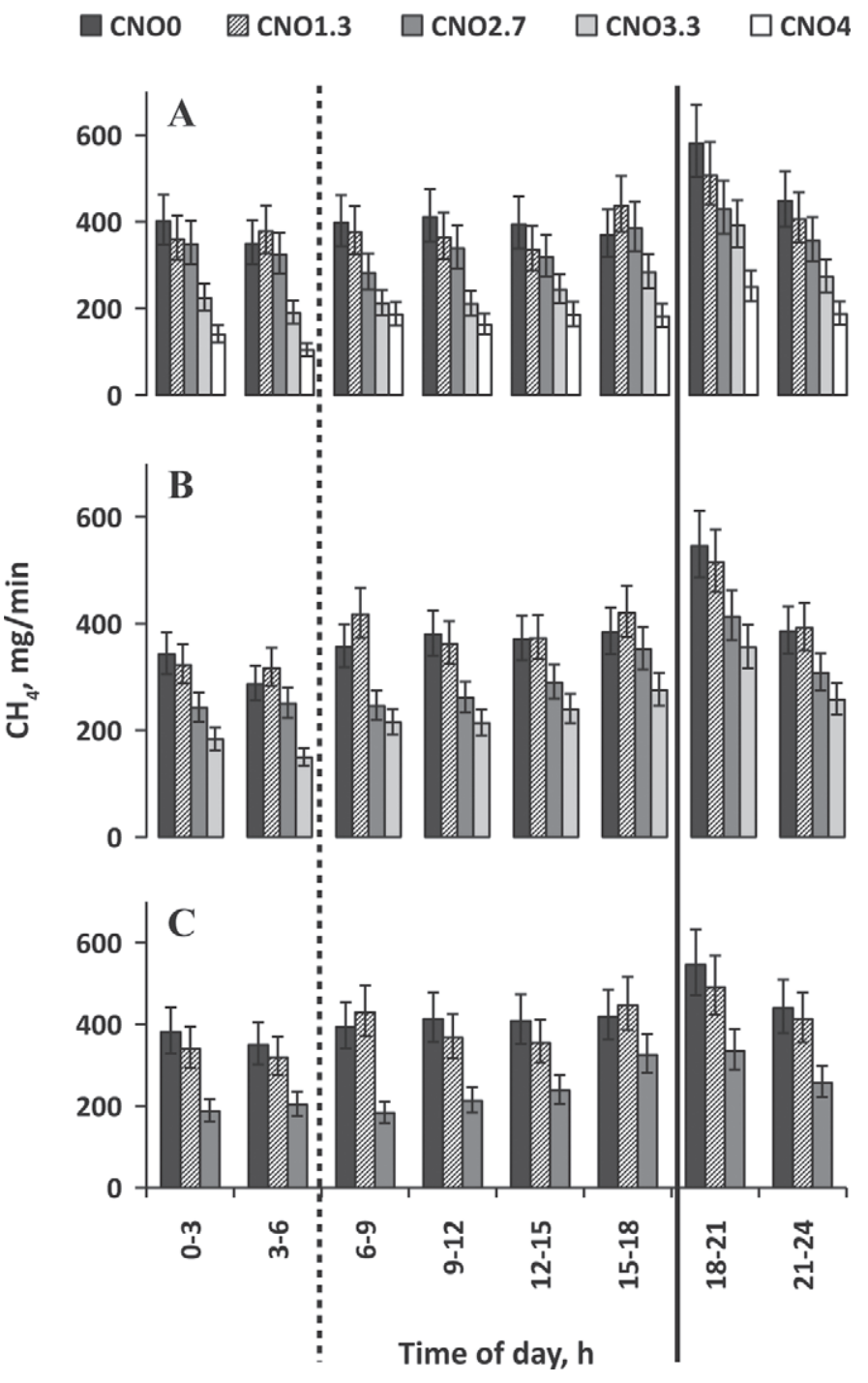

Figure 2. Diurnal enteric methane $\left(\mathrm{CH}_{4}\right)$ emissions during the habituation to different concentrations of dietary coconut oil (CNO) in primiparous and small secundiparous lactating dairy cows (experiment 1). Treatment diets were CNO0 (0.0\% CNO; dry basis), CNO1.3 (1.3\% CNO), CNO2.7 (2.7\% CNO), CNO3.3 (3.3\% CNO; A and $\mathrm{B}$ only), and CNO4 (4.0\% CNO; A only). Cows fed CNO4 were removed from the experiment after $10 \mathrm{~d}$. Cows fed CNO3.3 began the experiment following the removal of CNO4-fed cows. The results are expressed in 3 different periods. Figure $2 \mathrm{~A}=\mathrm{d} 1$ through 10 following introduction of treatments and included all dietary treatments (effects of treatment and time of day interaction: $P<0.001$; treatment $P<0.01$; time of day: $P<0.001$ ). Figure $2 \mathrm{~B}=\mathrm{d} 11$ through 22 and included all dietary treatments except CNO4 (effects of treatment and time of day interaction: $P<0.01$; treatment: $P<0.02$; time of day $P<0.001$ ). Figure $2 \mathrm{C}=\mathrm{d} 23$ through 34 and included treatments CNO0, CNO1.3, and CNO2.7 (effects of treatment and time of day interaction: $P<0.001$; treatment: $P<0.06$; time of day: $P<0.001$ ). Methane emissions were estimated from readings lasting 4 to $5 \mathrm{~min}$ during each 3-h time interval. Cows were fed ad libitum following the 3 to 6 -h and the 15 to 18 -h gas readings, but consumed the majority of their feed between afternoon and morning feedings. Histogram bars immediately to the right of the dashed line (morning feeding) and solid line (afternoon feeding) represent the first postfeeding measurement. Error bars are SEM within time interval for each treatment.
The delayed and gradual decrease in DMI observed in cows fed CNO2.7 and CNO3.3 may be a result of reduced ruminal NDFD found here and elsewhere (Külling et al., 2002; Reveneau et al., 2012; Hollmann and Beede, 2012). As a result, ruminal fill likely increased with prolonged feeding of 2.7 and $3.3 \%$ dietary CNO affecting regulation of DMI by distension (Allen, 1996). The mitigation of $\mathrm{eCH}_{4}$ emissions presumably was, in part, due to reduction in ruminal NDFD, because CNO2.7 and CNO3.3 reduced total-tract NDFD by approximately one-third. Previously, dietary MCFA were associated with severe reductions in total-tract NDFD (Külling et al., 2002; Hollmann and Beede, 2012) and, specifically, ruminal NDFD (Sutton et al., 1983; Reveneau et al., 2012). Thus, it likely took approximately 26 or $7 \mathrm{~d}$ of consuming CNO2.7 or CNO3.3, respectively, before $\mathrm{CNO}$ treatment substantially reduced ruminal NDFD.

\section{MY and Composition}

Patterns of SCMY (Figure 5) generally mirrored those of DMI (Figure 3A). Results of SCMY were not only a response to DMI, but also to dietary treatment effects on milk components. Concentrations greater than or equal to $2.7 \%$ CNO caused MFD (Table 2). Onset of MFD was after d 5 for cows fed CNO3.3 and CNO4 (Figure 6). Milk fat yield decreased continuously for 21 d for CNO3.3-fed cows, whereas fat yield stabilized following a 19-d decrease in CNO2.7-fed cows. The change in milk fat yield was similar to that of milk fat concentration. There appears to be a minimum biological milk fat concentration of approximately 2\% (Hollmann and Beede, 2012; K. J. Harvatine, Pennsylvania State University, University Park, personal communication), which likely will result in milk fat yield to stabilize at some point. Milk fat depression often occurs with concentrations equal to or greater than $2.5 \%$ dietary CNO (Hollmann et al., 2012; Hollmann and Beede, 2012; Reveneau et al., 2012). Relationship of yields and concentrations of individual milk FA with $\mathrm{eCH}_{4}$ emissions are reported elsewhere (DeLand et al., 2012).

Dietary CNO concentration influenced milk protein yield as cows adapted to different dietary CNO concentrations (experiment 1; Table 2). Yields decreased substantially between d 5 and 21 for CNO3.3-fed cows $(P<0.001$; Figure 7$)$. In contrast, milk protein concentration decreased in CNO3.3-fed cows $\left(P_{\text {interaction d } 5 \text { to } 21}\right.$ $<0.03)$, but not in CNO2.7-fed cows $\left(P_{\text {interaction d } 5 \text { to } 34}>\right.$ 0.9 ; Table 2). Additionally, milk protein concentration declined with CNO4 $(P<0.05$; Table 2). Moreover, milk protein concentration decreased by about 0.3 percentage units after cows were moved into their individual rooms (d -1 vs. 5 and $7 ; P_{t \text {-test }}<0.001$ ). This 

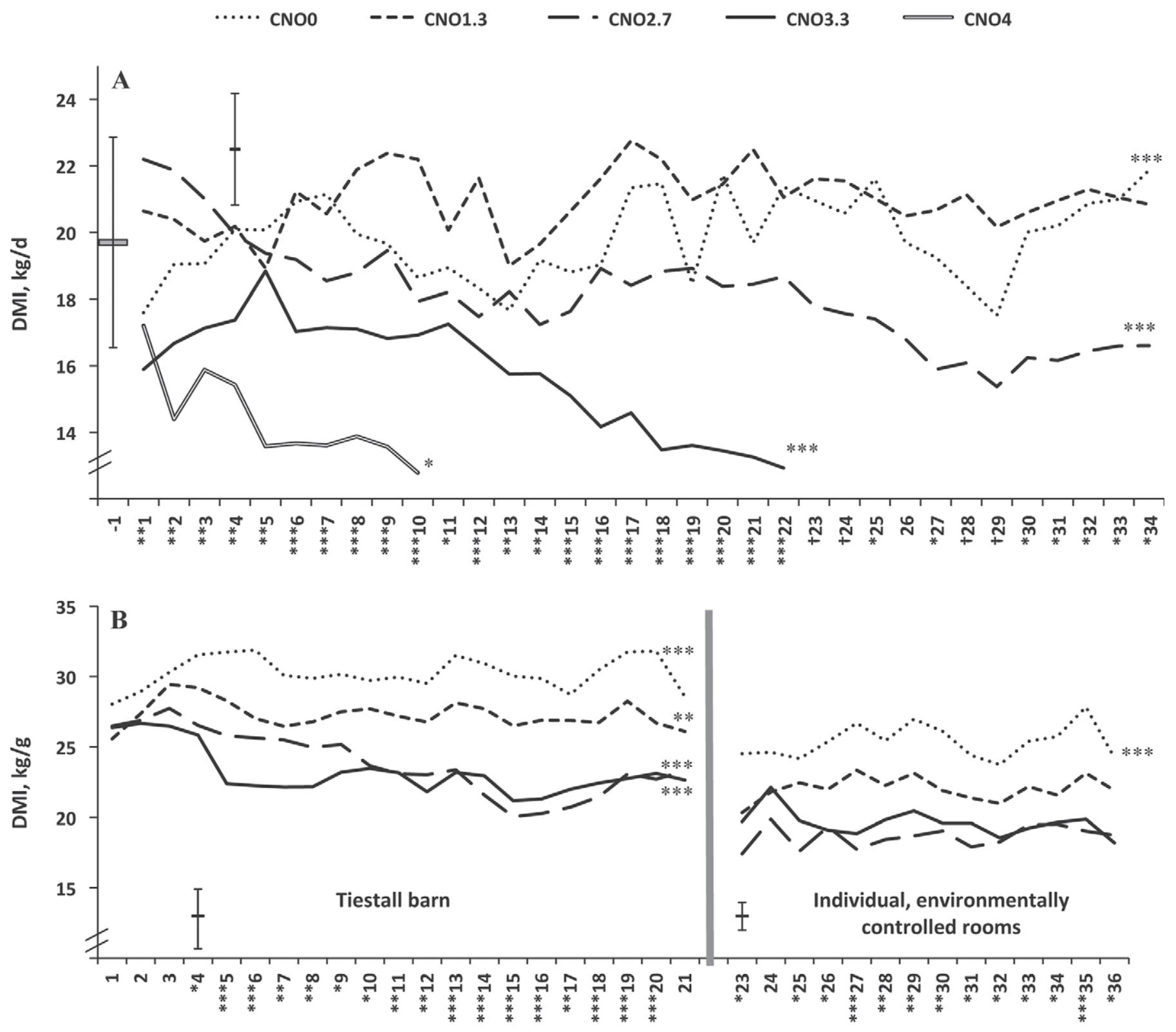

Days after introduction of dietary treatments

Figure 3. Dry matter intake during the habituation to different concentrations of dietary coconut oil (CNO) by primiparous and small secundiparous (A; experiment 1), and multiparous (B; experiment 2) lactating dairy cows. Treatment diets were CNO0 (0.0\% CNO; dry basis), CNO1.3 (1.3\% CNO), CNO2.7 (2.7\% CNO), CNO3.3 (3.3\% CNO), and CNO4 (4.0\% CNO). Symbols indicate significance of treatment within day (on $\mathrm{x}$-axis) and within individual treatments pooled across days (in plot): $\nmid P<0.10 ;{ }^{*} P<0.05 ;{ }^{* *} P<0.01$; ${ }^{* * *} P<0.001$. In experiment 1 (A), cows were kept individually in environmentally controlled rooms from $d-1$ through 34 . Cows fed CNO4 were removed from the experiment after $10 \mathrm{~d}$. Cows fed CNO3.3 began the experiment following the removal of CNO4-fed cows. Day -1 shows mean DMI and pooled SD ( \pm 3.16 ). Additional error bars represent pooled SEM for LSM of experimental period $( \pm 1.68)$. Interactions of treatment and day were $P<0.04$ for all treatments (d 1 through 10); $P<0.001$ for CNO0, CNO1.3, CNO2.7, and CNO3.3 (d 1 through 21); and $P<0.001$ for CNO0, CNO1.3, and CNO2.7 (d 1 through 34). In experiment 2 (B), cows were introduced to dietary treatments while fed in a tiestall barn and milked in a parlor from d 1 through 21. Effects of treatment and day interaction: $P<0.001$; treatment: $P<0.03$; day: $P<0.001$. Pooled SEM is shown ( \pm 0.81 ). Cows were moved into individual environmentally controlled rooms on d 22 (data omitted, indicated by vertical line). Effects of treatment and day interaction: $P<0.12$; treatment: $P<0.02$; day: $P<0.001$. Pooled SEM is shown $( \pm 0.98)$. 


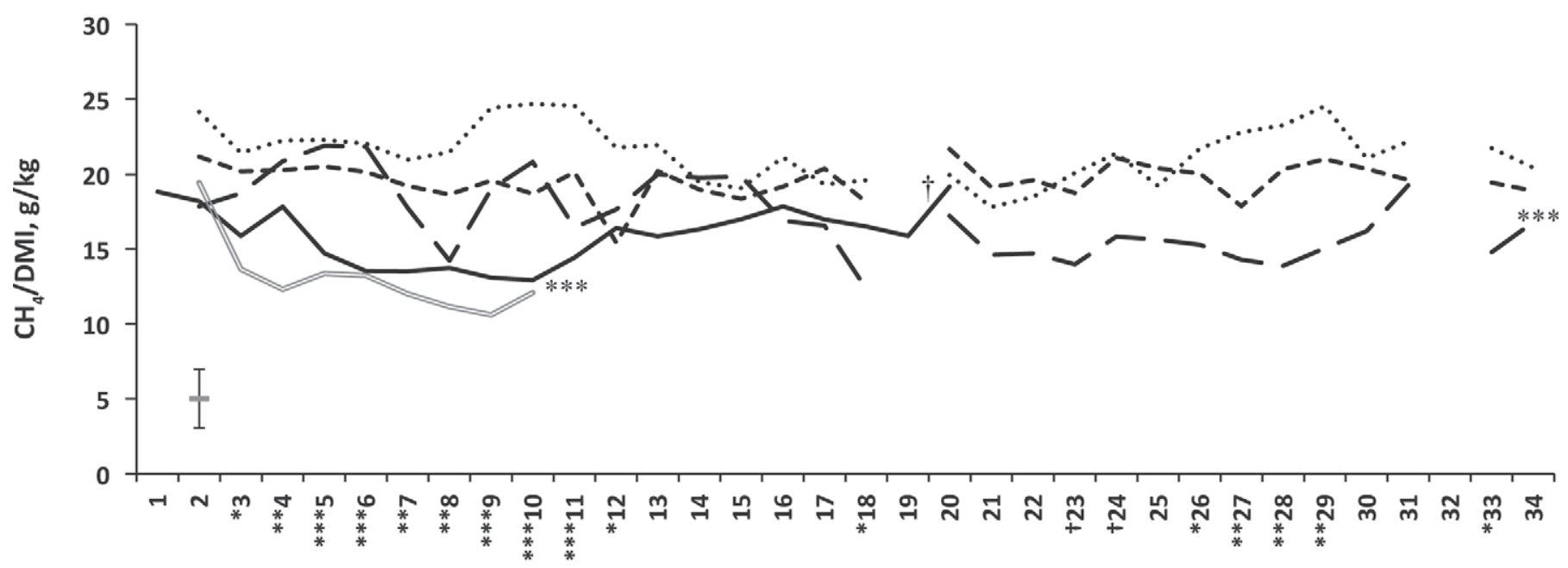

Days after introduction of dietary treatments

Figure 4. Methane $\left(\mathrm{CH}_{4}\right)$ emissions per unit of DMI during the habituation to different concentrations of dietary coconut oil (CNO) in primiparous and small secundiparous lactating dairy cows (experiment 1). Treatment diets were CNO0 (0.0\% CNO; dry basis), CNO1.3 (1.3\% CNO), CNO2.7 (2.7\% CNO), CNO3.3 (3.3\% CNO), and CNO4 (4.0\% CNO). Cows fed CNO4 were removed from the experiment after $10 \mathrm{~d}$ and replaced with different cows fed CNO3.3 on d 12. No data for $\mathrm{CH}_{4}$ were available for $\mathrm{d}-1,1,19$, and 32 of the experiment. Pooled SEM ( \pm 1.86 ) is shown. Symbols indicate significance of treatment within day (on x-axis) and within individual treatments pooled across days (in plot): $\dagger P<$ $0.10 ;{ }^{*} P<0.05 ;{ }^{* *} P<0.01 ; * * * P<0.001$.

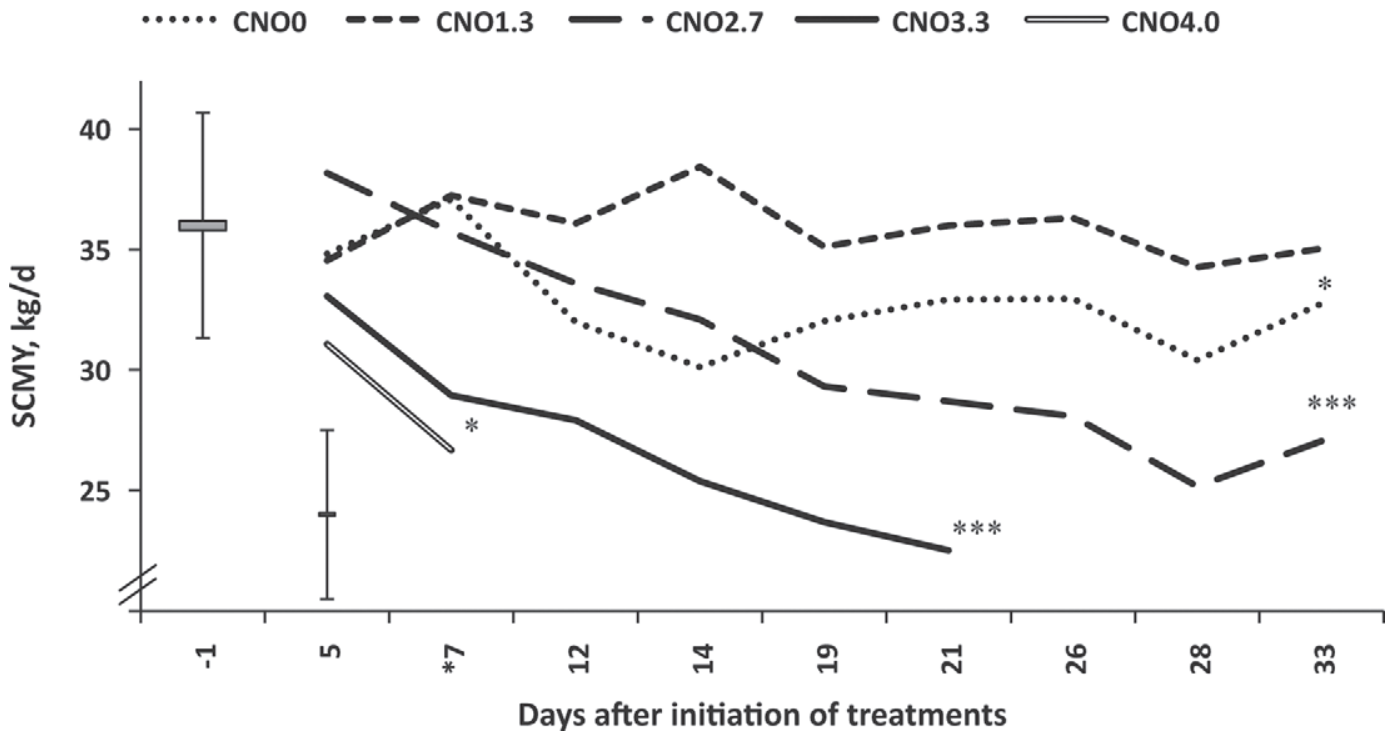

Figure 5. Solids-corrected milk yield (SCMY) during the habituation to different concentrations of dietary coconut oil (CNO) in primiparous and small secundiparous lactating dairy cows (experiment 1). Treatment diets were CNO0 (0.0\% CNO; dry basis), CNO1.3 (1.3\% CNO), CNO2.7 (2.7\% CNO), CNO3.3 (3.3\% CNO), and CNO4 (4.0\% CNO). Cows fed CNO4 were removed from the experiment after $10 \mathrm{~d}$. Cows fed CNO3.3 began the experiment following the removal of CNO4-fed cows. Day -1 shows mean SCMY and pooled SD ( \pm 4.67 ) and was used as covariate, if significant. Additional error bars represent pooled SEM for LSM of the experimental period $( \pm 3.50)$. Significance of variation is in Table 2. Symbols indicate significance of treatment within day (on $\mathrm{x}$-axis) and within individual treatments pooled across days (in plot): ${ }^{*} P<$ $0.05 ; * * * P<0.001$. 


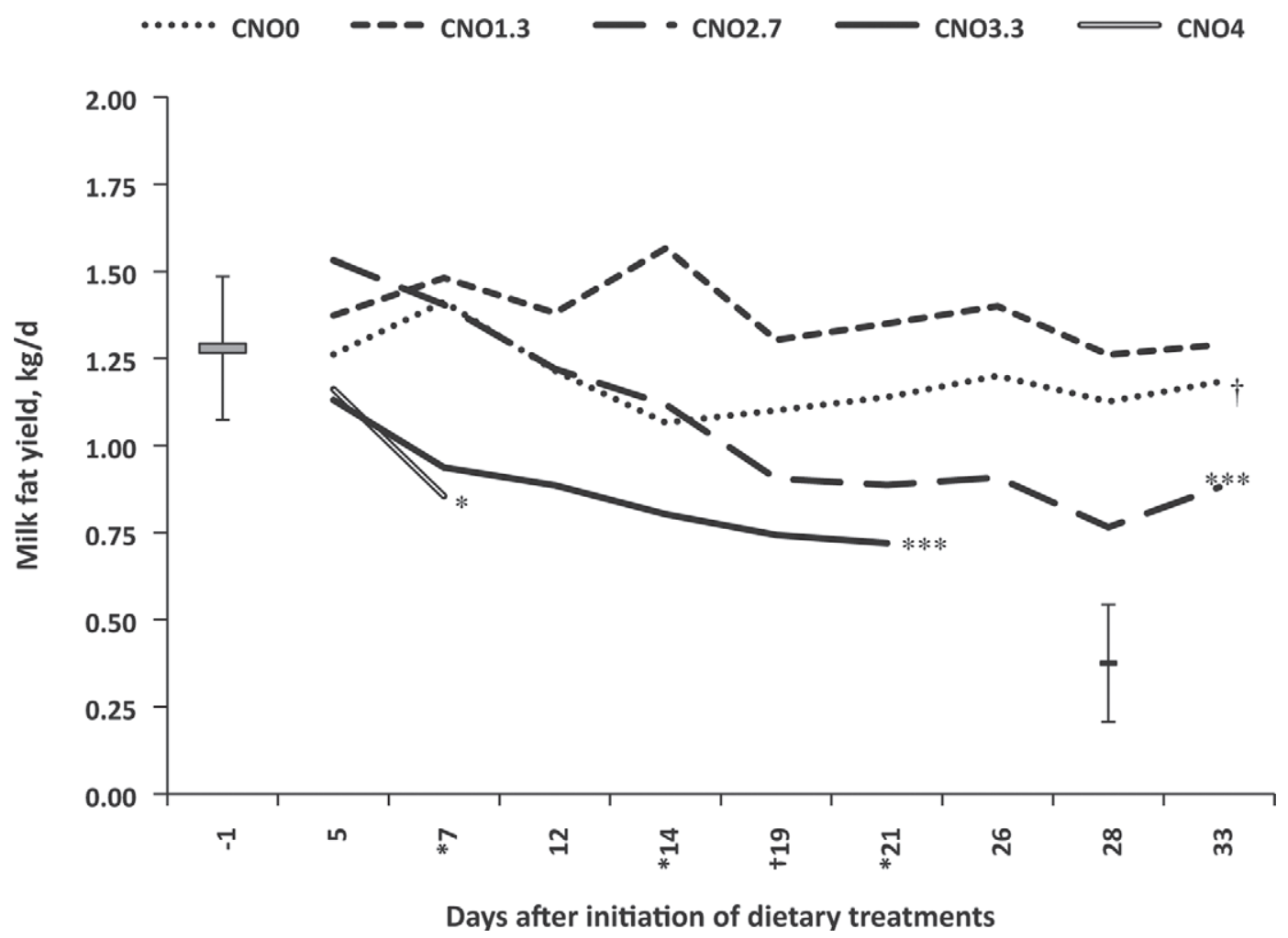

Figure 6. Milk fat yields during the habituation to different concentrations of dietary coconut oil (CNO) in primiparous and small secundiparous lactating dairy cows (experiment 1). Treatment diets were CNO0 (0.0\% CNO; dry basis), CNO1.3 (1.3\% CNO), CNO2.7 (2.7\% CNO), CNO3.3 (3.3\% CNO), and CNO4 (4.0\% CNO). Cows fed CNO4 were removed from the experiment after 10 d. Cows fed CNO3.3 began the experiment following the removal of CNO4-fed cows. Day -1 shows mean fat yield and pooled SD $( \pm 0.206)$ and was used as covariate. Additional error bars represent pooled SEM for LSM of experimental period $( \pm 0.168)$. Significance of variation is in Table 2 . Symbols indicate significance of treatment within day (on $\mathrm{x}$-axis) and within individual treatments pooled across days (in plot): $\nmid P<0.10 ;{ }^{*} P<0.05 ;{ }^{* * *} P<0.001$.

was likely due to a concurrent reduction in DMI upon placement in the environmental rooms in experiment 2 (Figure 3B). However, DMI was not recorded before the experiment for cows in experiment 1.

\section{General Discussion}

Dietary $\mathrm{CNO}$ reduced $\mathrm{eCH}_{4}$ emissions per unit of DMI (Figure 4) somewhat differently from DMI (Figure $3 \mathrm{~A})$. Therefore, reduced DMI explained only part of the mitigation in $\mathrm{eCH}_{4}$ emissions. In contrast, reducing intake as a multiple of maintenance energy requirement will increase energetic loss as $\mathrm{eCH}_{4}$ per unit of feed energy consumed (Blaxter and Clapperton, 1965). Thus, concomitantly reduced ruminal NDFD contributed to mitigation of $\mathrm{eCH}_{4}$ emissions with dietary $\mathrm{CNO}$ in the present study. Stoichiometrically, ruminal fermentation of NDF produces more acetate and more $\mathrm{eCH}_{4}$ than ruminal fermentation of NFC (Blaxter and Clapperton, 1965). Thus, a concurrent depression in ruminal NDFD and DMI would reduce $\mathrm{eCH}_{4}$ emission per unit of DMI. Dietary CNO, in substitution for soy hulls, a highly fermentable source of NDF, may have contributed to reduced ruminal NDFD and, consequently, $\mathrm{eCH}_{4}$ emitted per unit of DMI. However in that case, we would expect (1) a linear decrease in NDFD with increased $\mathrm{CNO}$ concentration and (2) no interaction of CNO concentration and time on treatment for $\mathrm{eCH}_{4} / \mathrm{DMI}$. Instead, NDFD of CNO1.3-fed cows were similar to those fed $\mathrm{CNO} 0$ and not intermediate to those fed CNO0 and $\mathrm{CNO} 2.7$; and, $\mathrm{eCH}_{4} / \mathrm{DMI}$ decreased during the habituation period in cows fed $2.7 \%$ or more CNO. Thus, it is unlikely that NDFD was a response to dietary soy hulls. The simultaneous depression in SCMY per cow exacerbates the environmental impact of dietary CNO to mitigate $\mathrm{eCH}_{4}$ from lactating cows (Hollmann and Beede, 2010). Mitigation of $\mathrm{eCH}_{4}$ by means of depressing NDFD contradicts the use of ruminant livestock in food production systems.

Increased dietary CNO concentration induced MFD, except with CNO1.3 (Figure 6). Remarkably, increased dietary CNO also accelerated MFD, in similar fashion as increased $\mathrm{CNO}$ expedited reduction in $\mathrm{eCH}_{4}$ emissions. Milk fat concentration, indicative of the 


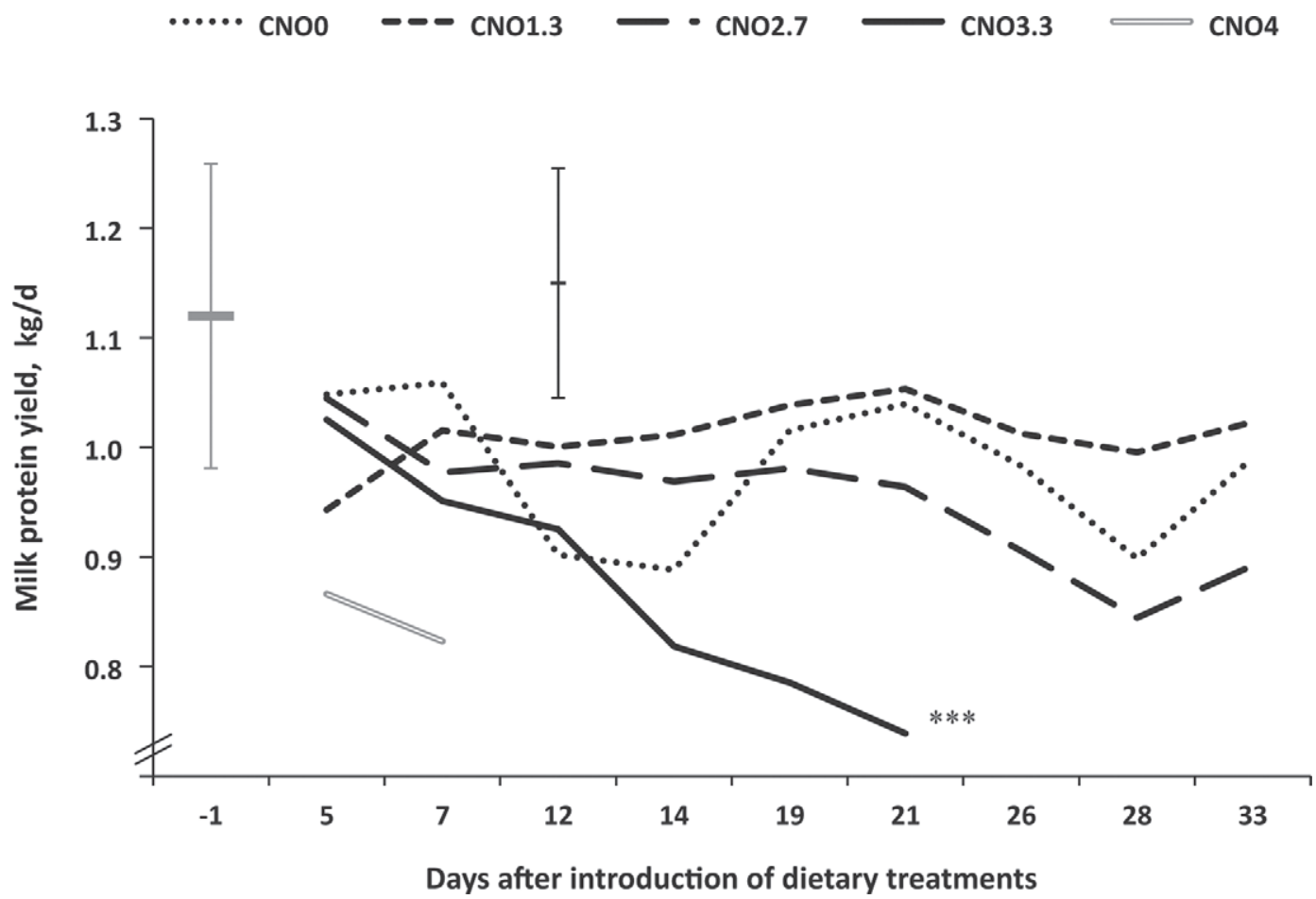

Figure 7. Milk protein yields during the habituation to different concentrations of dietary coconut oil (CNO) in primiparous and small secundiparous lactating dairy cows (experiment 1). Treatment diets were CNO0 (0.0\% CNO; dry basis), CNO1.3 (1.3\% CNO), CNO2.7 (2.7\% CNO), CNO3.3 (3.3\% CNO), and CNO4 (4.0\% CNO). Cows fed CNO4 were removed from the experiment after 10 d. Cows fed CNO3.3 began the experiment following the removal of CNO4-fed cows. Day -1 shows mean protein concentration and pooled SD ( \pm 0.139$)$ and was used as covariate, if significant. Additional error bars represent pooled SEM for LSM of the experimental period $( \pm 0.105)$. Significance of variation is in Table 2. Symbols indicate significance of treatment within individual treatments pooled across days (in plot): ${ }^{* * *} P<0.001$.

amount of fat per unit of milk produced, dropped fast and precipitously following introduction of CNO3.3 or CNO4. In contrast, milk fat decreased at a slower rate in cows fed CNO2.7 compared with those fed CNO3.3 or $\mathrm{CNO} 4$. Often, a low ratio of ruminally fermented NDF to ruminally fermented NFC accompanies MFD (Bauman and Griinari, 2001; Hollmann et al., 2012). This suggests that ruminal NDFD mirrored the extent and temporal pattern of MFD.

Previously, we speculated that dietary CNO may affect DMI in dairy cows in multiple ways (Hollmann and Beede, 2012). Medium-chain FA in CNO increase oxidation of fuels (Allen et al., 2009) or evoke hormonal responses post-absorption (Feltrin et al., 2004). As a short-term response, DMI may be downregulated within a few days following $\mathrm{CNO}$ introduction (e.g., the instantaneous DMI reduction with $\mathrm{CNO} 4)$. However, this type of short-term regulation would unlikely result in temporal reduction in DMI as shown in the present experiments. Rather, the less precipitous and slower rate of DMI responses with lower $\mathrm{CNO}$ concentrations in both experiments suggests an additional, intermediate regulation of DMI. Integration of the concurrent rate of $\mathrm{eCH}_{4}$ and $\mathrm{eCH}_{4} / \mathrm{DMI}$ reduction and MFD points toward reduced ruminal NDFD over time. Potentially then, increased ruminal retention time of NDF due to reduced digestibility likely increased the ruminal NDF pool and subsequently contributed to concurrent DMI depression by ruminal distention (Allen, 1996).

\section{CONCLUSIONS}

Dietary CNO greater than or equal to $2.7 \%$, dry basis, reduced $\mathrm{eCH}_{4}$ emissions in lactating dairy cows during habituation to $\mathrm{CNO}$ treatment. Reduction in $\mathrm{eCH}_{4}$ emissions was greater during the first half than the second half of the day. Increased CNO concentration related to an expedited onset of $\mathrm{eCH}_{4}$ and $\mathrm{eCH}_{4}$ / DMI mitigation, but also of DMI, SCMY, and milk fat yield reduction. The responses in $\mathrm{eCH}_{4}$ emissions and DMI were rapid and precipitous with $\mathrm{CNO} 4$, but more delayed and progressive with CNO3.3 and especially with CNO2.7. Moreover, $2.7 \%$ or more of dietary CNO depressed total-tract NDFD during wk 5 of the experiment. 


\section{ACKNOWLEDGMENTS}

We thank West Central Cooperative (Ralston, IA) for the donation of SoyPLUS. We also appreciate the support of R. E. Kreft and the farm crew at the Michigan State University Dairy Teaching and Research Center (East Lansing) and of B. Story at the Michigan State University Feed Mill. S. Hengemuehle, D. G. Main, L. E. Gault, K. M. Lebbin, O. N. Genther, N. Schroeder, and S. M. Carrier in the Animal Science Department and J. A. Zyskowski at the Nutrition Laboratory (Diagnostic Center for Population Animal Health at Michigan State University) provided technical assistance. Numerous undergraduate students assisting with animal care, data collection, sample preparation, and parts of the laboratory analyses were indispensable. The C. E. Meadows Endowment supported this research.

\section{REFERENCES}

Allen, M. S. 1996. Physical constraints on voluntary intake of forages by ruminants. J. Anim. Sci. 74:3063-3075.

Allen, M. S., B. J. Bradford, and M. Oba. 2009. The hepatic oxidation theory of the control of feed intake and its application to ruminants. J. Anim. Sci. 87:3317-3334.

AOAC (Association of Official Analytical Chemists). 1990. Official Methods of Analysis. Vol. 2. 15th ed. AOAC, Arlington, VA.

Bauman, D. E., and J. M. Griinari. 2001. Regulation and nutritional manipulation of milk fat: Low-fat milk syndrome. Livest. Prod. Sci. 70:15-29.

Blaxter, K. L., and J. L. Clapperton. 1965. Prediction of amount of methane produced by ruminants. Br. J. Nutr. 19:511-522.

Blaxter, K. L., and J. Czerkawski. 1966. Modifications of the methane production of the sheep by supplementation of its diet. J. Sci. Food Agric. 17:417-421

DeLand, K. E., M. Hollmann, J. C. Ploetz, W. J. Powers, D. K. Beede, and A. L. Lock. 2012. Potential use of specific milk fatty acids to predict enteric methane emissions from lactating dairy cows. J. Dairy Sci. 95(E.-Suppl. 2):433. (Abstr.)

Feltrin, K. L., T. J. Little, J. H. Meyer, M. Horowitz, A. J. P. M. Smout, J. Wishart, A. N. Pilichiewicz, T. Rades, I. M. Chapman, and C. Feinle-Bisset. 2004. Effects of intraduodenal fatty acids on appetite, antropyloroduodenal motility, and plasma CCK and GLP-1 in humans vary with their chain length. Am. J. Physiol. Regul. Integr. Comp. Physiol. 287:R524-R533.

Goering, H. H., and P. J. Van Soest. 1970. Forage Fiber Analysis (Apparatus, Reagents, Procedures, and Some Applications). Agric.
Handbook No. 379. Agricultural Research Service-US Department of Agriculture (ARS-USDA), Washington, DC.

Hollmann, M., and D. K. Beede. 2010. Limited suitability of dietary coconut oil to reduce enteric methane emissions from dairy cattle. Page 112 in Proc. Int. Conf. Greenhouse Gases Anim. Agric. Accessed Mar. 7, 2012. http://www.ggaa2010.org/pdfs/Proceedings_Abstracts.pdf.

Hollmann, M., and D. K. Beede. 2012. Comparison of effects of dietary coconut oil and animal fat blend on lactational performance of Holstein cows fed a high-starch diet. J. Dairy Sci. 95:1484-1499.

Hollmann, M., W. J. Powers, A. C. Fogiel, J. S. Liesman, N. M. Bello, and D. K. Beede. 2012. Enteric methane emissions and lactational performance of Holstein cows fed different concentrations of coconut oil. J. Dairy Sci. 95:2602-2615.

Jordan, E., D. K. Lovett, M. Hawkins, J. J. Callan, and F. P. O'Mara. 2006. The effect of varying levels of coconut oil on intake, digestibility and methane output from continental cross beef heifers. Anim. Sci. 82:859-865.

Kinsman, R., F. D. Sauer, H. A. Jackson, and M. S. Wolynetz. 1995. Methane and carbon dioxide emissions from dairy cows in full lactation monitored over a six-month period. J. Dairy Sci. 78:27602766 .

Külling, D. R., F. Dohme, H. Menzi, F. Sutter, P. Lischer, and M. Kreuzer. 2002. Methane emissions of differently fed dairy cows and corresponding methane and nitrogen emissions from their manure during storage. Environ. Monit. Assess. 79:129-150.

Li, W., W. Powers, and G. M. Hill. 2011. Feeding DDGS to swine and resulting impact on air emissions. J. Anim. Sci. 89:3286-3299.

Littell, R. C., W. W. Stroup, and R. J. Freund. 2002. SAS ${ }^{\circledR}$ for Linear Models. SAS Institute, Cary, NC. http://www.sas.com/pubs.

Machmüller, A. 2006. Medium-chain fatty acids and their potential to reduce methanogenesis in domestic ruminants. Agric. Ecosys. Environ. 112:107-114.

NRC. 2001. Nutrient Requirements of Dairy Cattle. 7th ed. National Academic Press, Washington, DC.

Reveneau, C., S. K. R. Karnati, E. R. Oelker, and J. L. Firkins. 2012. Interaction of unsaturated fat or coconut oil with monensin in lactating dairy cows fed 12 times daily. I. Protozoal abundance, nutrient digestibility, and microbial protein flow to the omasum. J. Dairy Sci. 95:2046-2060.

Sutton, J. D., R. Knight, A. B. McAllan, and R. H. Smith. 1983 Digestion and synthesis in the rumen of sheep given diets supplemented with free and protected oils. Br. J. Nutr. 49:419-432.

Tyrrell, H. F., and J. T. Reid. 1965. Prediction of the energy value of cow's milk. J. Dairy Sci. 48:1215-1223.

Van Soest, P. J., J. B. Robertson, and B. A. Lewis. 1991. Methods for dietary fiber, neutral detergent fiber, and nonstarch polysaccharides in relation to animal nutrition. J. Dairy Sci. 74:3583-3597.

Verdi, R. J., D. M. Barbano, M. E. Dellavalle, and G. F. Senyk. 1987. Variability in true protein, casein, nonprotein nitrogen, and proteolysis in high and low somatic cell milks. J. Dairy Sci. 70:230-242. 